\title{
French Hydrangea for Gardens in North and Central Florida1
}

Gary W. Knox ${ }^{2}$

French hydrangea (Hydrangea macrophylla) is a shade-preferring shrub producing ball-shaped or flat clusters of white, pink, blue or purple flowers, depending on soil conditions and cultivar. "Mophead" or "hortensia" hydrangeas (Figure 1) have ball-shaped flower clusters, whereas "lacecap" hydrangeas have flat clusters of tiny, spidery flowers surrounded by a ring of prominent flowers (Figure 2). French hydrangea is the most widely grown species of Hydrangea.

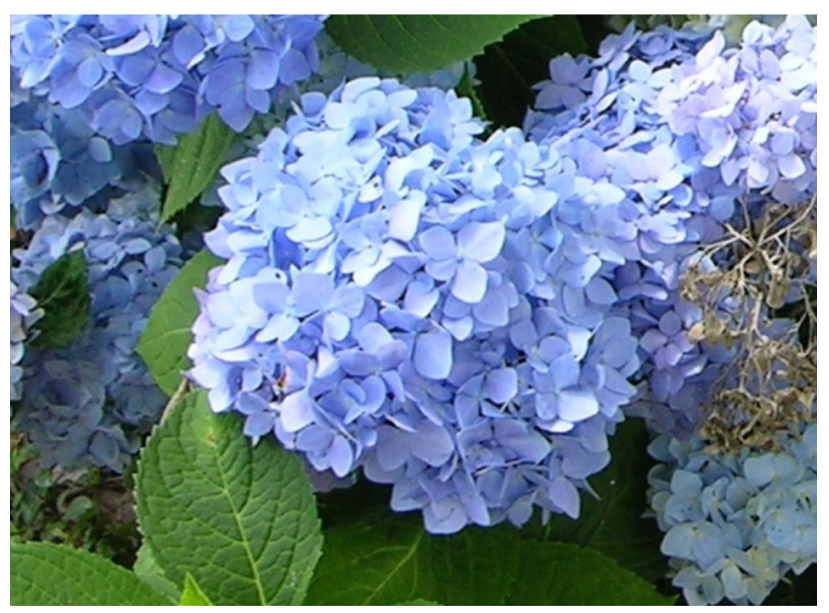

Figure 1. The mophead flower of 'Decatur Blue' in its blue form.

\section{Origin and Development of French Hydrangea}

Two forms of Hydrangea macrophylla are native to eastern Asia. Bigleaf hydrangea, Hydrangea macrophylla var. macrophylla, is native to China and coastal areas of Japan. Mountain hydrangea, $H$. macrophylla var. serrata, is native to China and upland areas of Japan and Korea. Mountain hydrangea is generally smaller in size and flowers earlier. Some experts consider it more cold-hardy than bigleaf hydrangea. The two natural varieties are otherwise very similar, and both types may produce mophead or lacecap flowers, depending on the selection.

French hydrangea has long been valued as a garden plant in Japan. Hundreds of old cultivars are recorded there, and Japanese breeders continue to develop new forms. When introduced to Europe and the Americas in 1789, these hydrangeas acquired the common name "French hydrangea." The shrub became hugely popular as a garden and potted flowering plant in the late 1800 s and early 1900 s before falling out of favor in the mid 1900s. Today, gardeners and landscapers alike have renewed

1. This document is ENH1069, one of a series of the Environmental Horticulture Department, Florida Cooperative Extension Service, Institute of Food and Agricultural Sciences, University of Florida. Original publication date April, 2007. Visit the EDIS Web Site at http://edis.ifas.ufl.edu.

2. Extension Specialist and Professor of Environmental Horticulture, University of Florida/IFAS, North Florida Research and Education Center, 155 Research Road, Quincy, FL 32351. Jan. 2007.

The Institute of Food and Agricultural Sciences (IFAS) is an Equal Opportunity Institution authorized to provide research, educational information and other services only to individuals and institutions that function with non-discrimination with respect to race, creed, color, religion, age, disability, sex, sexual orientation, marital status, national origin, political opinions or affiliations. U.S. Department of Agriculture, Cooperative Extension Service, University of Florida, IFAS, Florida A. \& M. University Cooperative Extension Program, and Boards of County Commissioners Cooperating. Larry Arrington, Dean 


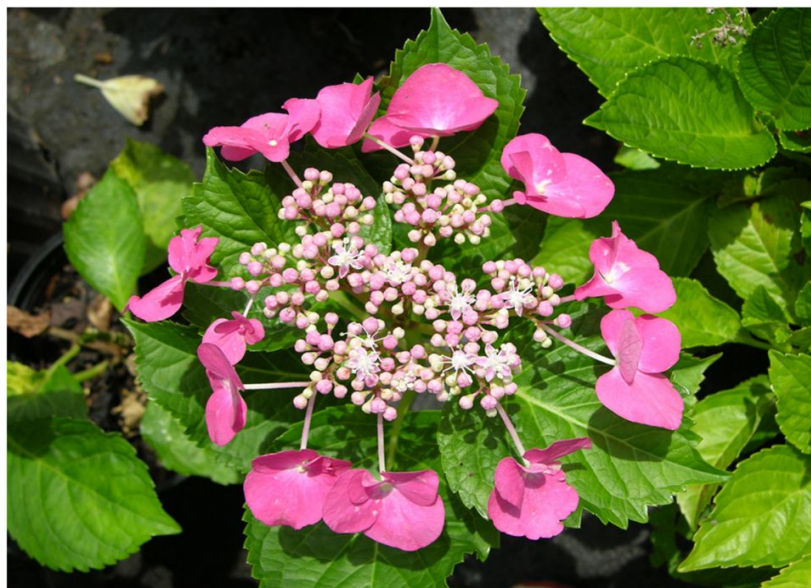

Figure 2. The lacecap flower of 'Mowe' in its pink form.

appreciation of French hydrangea because it flowers in shade, often produces blue flowers, and is considered an "heirloom" plant that reminds us of the garden heritage of our forefathers.

French hydrangea (Hydrangea macrophylla) is not documented in any undisturbed natural areas in Florida. It has been evaluated using the IFAS Assessment of the Status of Non-Native Plants in Floridas Natural Areas (Fox et al. 2005), is not considered a problem species, and therefore may be recommended for use in Florida.

\section{Reflowering French Hydrangeas}

The recent discovery and development of reflowering French hydrangeas revolutionized the market and demand for hydrangeas. Reflowering hydrangeas produce an initial flush of flowers followed by sporadic flowering or later flushes of flowers in the same growing season. Though some older cultivars are considered "free-flowering," it is the newer, "everblooming" cultivars that have been lauded and subsequently promoted with elaborate marketing campaigns.

The first everblooming French hydrangea to be recognized and commercially promoted was discovered by noted plantsman, Dr. Michael Dirr, in the trial garden of a wholesale nursery in Minnesota. One of the nursery employees noticed that a neighbor's French hydrangea flowered late in the year, and he obtained permission to propagate and test the plant. Dr. Dirr recognized that the plant had value as a garden plant along with great commercial potential. This plant was given the cultivar name of
'Bailmer' and is now widely known as Endless Summer ${ }^{\circledR}$ hydrangea.

Everblooming French hydrangea cultivars provide more garden impact and strengthen the ongoing appreciation of hydrangea. This revitalized enthusiasm is bringing greater attention to the historic varieties of French hydrangea as well as inviting efforts to improve hydrangea through new selection and breeding programs. For more information on new cultivars, refer to ENH1034, New Hydrangeas for North and Central Florida: Bigleaf and Mountain Hydrangeas (http://edis.ifas.ufl.edu/EP287).

\section{Growing French Hydrangea}

\section{Culture}

French hydrangea requires shade (either continuous shade or morning sun and afternoon shade), moist (but not wet) soils, and cool winters. Within these environmental criteria, French hydrangea is adapted to north and central Florida, although good site selection and plant care increases in importance the further south it is planted. After plants are well established, French hydrangea is moderately drought tolerant and moderately salt tolerant.

\section{Description and Growth Habit}

French hydrangea grows as a mounded or rounded shrub composed of stout, upright stems that usually are unbranched. Leaves are large, often 4 to 8 inches long and 2 to 5 inches wide, and leathery. Leaf color ranges from medium to dark green and from dull to glossy, depending on cultivar.

French hydrangea is deciduous in most areas of Florida, dropping leaves in autumn as days shorten, especially after cool weather. However, hydrangea may not drop all leaves in frost-free areas or during mild autumns and winters. In these cases, remaining leaves often fall with onset of new growth in spring.

French hydrangea is fully cold hardy throughout Florida and plants rarely die back. Consequently, French hydrangea often reaches a mature size of 6 feet tall and wide, and it can grow as large as 12 feet tall and wide. When planting French hydrangea in the garden, place it in a location providing enough space 
for the plant to mature. Alternatively, use a cultivar known to mature at a smaller size or plan for occasional pruning to reduce plant size.

\section{Pruning}

Most plants will need little or no pruning unless dieback occurs or plants outgrow their preferred size. Prune plants when needed in mid to late summer, removing no more than a third to a half of each main stem. Pruning in mid to late summer allows for current year's flowering as well as sufficient time for some regrowth and for flower buds to form on the new growth.

\section{Use in the Garden}

French hydrangea is valued as a garden plant for its ability to flower in shade and for its blue flowers. Sooner or later, most gardens develop areas shaded by trees, house walls or other structures. Shade limits the plants that can be grown in these areas. French hydrangea is well adapted to shaded areas, and few other plants can produce as many colorful flowers under shade. In addition, French hydrangea produces relatively rare and thus highly valued blue flowers on most Florida soils.

Large leaves and flower clusters lend a coarse textured appearance to French hydrangea. Within the environmental constraints of shade and moist soil, French hydrangea can be an attractive component of a mixed shrub bed or border where their coarse textured leaves are an effective foil for finer textured plants and where their flower clusters can create bursts of color. A mixed bed also will "hide" the leafless stems in winter, or at least make them less noticeable. French hydrangea is well suited for use in large massed beds where their peak flowering in early summer will create impressive swaths of color. Reflowering types of French hydrangea are especially useful for their showy display of flowers in early summer followed by sporadic flowering throughout the rest of the year.

Conversely, most people may not want to use French hydrangea in a foundation planting because the plant loses its leaves in winter and would thus expose the structure behind it. Similarly, it may not be a desirable specimen plant because the winter appearance of the leafless, unbranched stem structure is too open to offer a prominent profile. Furthermore, the upright, leafless stems create a more vertical effect rather than the mounded appearance presented by the fully leafed plant.

\section{Use in Containers}

French hydrangea has long been used as a small flowering pot plant that is discarded after flowering. Many cultivars have been developed exclusively for this use. Container-grown French hydrangeas are still popular flowering plants at holidays such as Mother's Day and Easter. If planted in the garden, some will grow and flower the same as those purchased for garden use. However, many of these cultivars are not adapted to garden use in Florida and often are particularly susceptible to diseases.

French hydrangeas bred for garden use also perform well in a large container provided the container is placed in shade and the potting mix is moisture-retentive yet well-drained. Remember the plant will be leafless in winter. Smaller, compact cultivars are better-adapted and easier to manage in containers.

\section{Flowering}

French hydrangea flowers for 5 to 9 weeks in late spring or early summer. The mophead or lacecap flowers develop from buds formed in the tips of stems the previous year (on old wood). Most older cultivars bloom just once. Some French hydrangeas also form flower buds the previous year in buds up and down the stems (not just at the tips). These flower buds may develop and flower weeks or months after the terminal flower buds bloom in early summer. French hydrangeas with this pattern of flowering are called "free-flowering."

"Everblooming" hydrangeas produce flowers from buds formed the previous year and also from buds formed on new growth. In this latter case, flower buds form in the tips of new growth, and these buds will continue to develop and ultimately flower later in the same year. Technically called "remontant," French hydrangeas with this characteristic have the ability to flower almost continuously throughout the growing season. Some 
of these hydrangeas flowered 30 weeks or more at the University of Florida/IFAS North Florida Research and Education Center. Everblooming types of French hydrangea are especially popular and may soon dominate the nursery trade.

\section{Flower Types}

"Mophead" or "hortensia" type hydrangeas form ball-shaped flower clusters 3 to 8 inches across (Figure 1). Most of these individual flowers are sterile and do not produce seed. These sterile flowers are characterized by four wide, showy petal-like sepals (hereafter called "petals"), each of which may be 1 to 3 inches across.

"Lacecap" hydrangeas have flat clusters 3 to 8 inches across composed of tiny, spidery flowers surrounded by a ring of prominent flowers (Figure 2). Each spidery flower is $1 / 4$ to $1 / 2$ inch across and fertile, with the capacity to produce seed. The showy, prominent flowers on the outer periphery of the flower clusters are sterile and are similar to those found on mophead hydrangea. As with mophead types, sterile flowers have four wide, showy petals.

\section{Characteristics of Individual Flowers}

Spidery fertile and showy sterile flowers may be white, dark pink, pink, purple, or blue on both mophead and lacecap flower types. Showy sterile flower petals may have picotee patterns such that each petal is edged in a thin margin of white. Petals also may be serrated, creating an interesting lacy appearance.

As flowers age or are pollinated, petal color may change to green, blue or burgundy. Individual flowers also may invert themselves so that the undersides ("backs") of the petals are displayed. Aging flowers may be quite ornamental, and may extend the season of flower color for many weeks (Figure 3).

\section{Flower Colors: Blue, Purple, Pink, Red and White}

Most French hydrangeas produce blue, purple or pink flowers, depending on cultivar and soil conditions. Many people are aware that soil acidity or

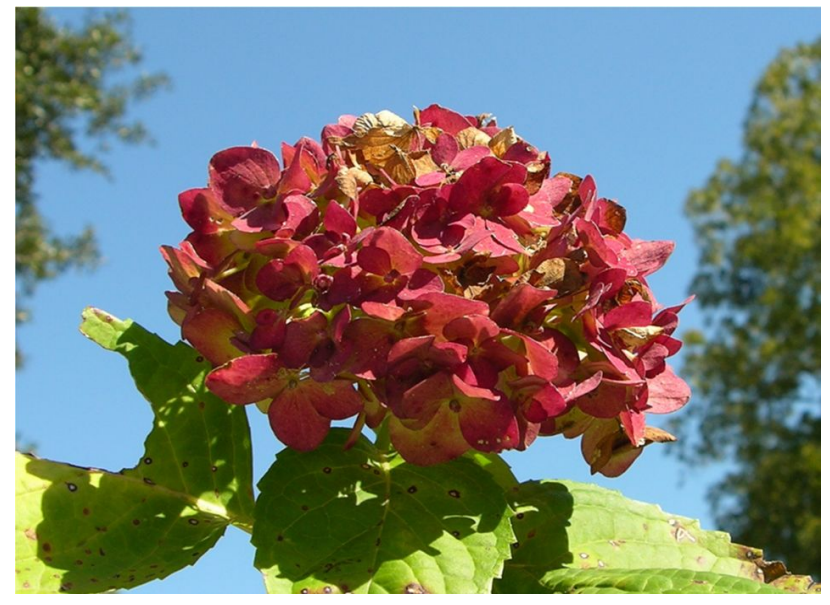

Figure 3. Flowers of Blushing Bride ${ }^{\mathrm{TM}}$ turn burgundy as they age, extending the season of flower color for several weeks.

alkalinity affects and changes French hydrangea flower color, but most don't know why.

\section{Amounts of Flower Pigment and Aluminum Determine Blue or Pink Flower Color}

The amount of a flower pigment, delphinidin 3-monoglucoside, and the amount of aluminum within flower cells determines the flower color of French hydrangea. This flower pigment combines with aluminum to form the blue color; without aluminum, pigment color is pink. The intensity and shade of flower color depends on relative amounts of pigment and aluminum. Resulting flower color can vary from intense blue to purple to pink to almost red.

\section{Soil pH Affects Aluminum and Flower Color}

The amount of aluminum in the flower is determined by the amount of aluminum in the soil, soil $\mathrm{pH}$, phosphorus in the soil, and the plant's ability to absorb aluminum through plant roots. $\mathrm{pH}$ is a measure of acidity or alkalinity. In acidic soils $(\mathrm{pH}$ 5.5 or lower), aluminum assumes a form that is easily absorbed by plant roots, and thus flowers are predominately blue. In soils where the $\mathrm{pH}$ is 6.5 or higher, aluminum is unavailable and flower color is pink. Purple flowers are produced when soil $\mathrm{pH}$ is between 5.5 and 6.5 or when a predominantly-pink or "red" cultivar is grown in acid soil. Sometimes a single plant will have both blue and pink flowers because of varying soil conditions around the plant. 
Most soils in north and central Florida are slightly acid ( $\mathrm{pH}$ between 5.0 and 6.5). Thus, most French hydrangea flowers are blue or purple. Exceptions occur when French hydrangea is planted in soils derived from limestone, marl or sea shells; when soils are contaminated by alkaline mortar or concrete debris (left after construction); when beds are situated next to stucco walls, mortared walls, concrete foundations and sidewalks (where alkaline runoff affects soil); or when irrigation water is alkaline and contains significant amounts of dissolved limestone. These situations often will result in higher soil $\mathrm{pH}$ and purple or pink flowers.

\section{Soil Phosphorus Content Affects Aluminum Levels in Flowers}

Another soil element and plant nutrient, phosphorus, can confound development of blue flower color. Phosphorus interacts with and effectively ties up available aluminum in the soil. Thus if soil phosphorus levels are high, pink flowers will result, even if soil is acidic and aluminum is present. This is important because many Florida soils naturally contain high levels of phosphorus or are former agricultural lands that received excessive phosphorus fertilization. A soil test will measure soil $\mathrm{pH}$ and phosphorus content to provide information on potential flower color of French hydrangea.

\section{White- and "Red"-Flowered French Hydrangeas Are Different}

Plant genetics also can affect flower color. Some cultivars produce flowers that are predominately white. These flowers have very little of the pigment delphinidin 3-monoglucoside. Since small amounts of this pigment usually are present, white flowers often are tinted pink or blue, depending on availability of aluminum.

Some cultivars produce flowers that are predominately dark pink, "red" or purple. The roots of these cultivars are poor absorbers of aluminum. Since they can't absorb much aluminum, the flower pigment is predominately in the pink form.

Cultivars with "red" flowers generally are reddest in cooler climates such as the Pacific Northwest. These cultivars rarely produce red flowers in Florida, and at best the flowers are dark pink.

\section{Changing Flower Color to Blue, Purple or Pink}

Flower color of blue- to pink-flowered French hydrangea can be changed to blue, purple or pink by manipulating aluminum level and availability. Color of white-flowered French hydrangea cannot be changed. "Red"-flowered French hydrangea in Florida can be manipulated only between dark pink and purple.

If natural soil doesn't produce the desired flower color, consider growing French hydrangea in containers or raised beds in which aluminum level, soil conditions and flower color can be controlled more easily. Florida soils may provide some unique challenges in changing flower color, particularly for soils high in phosphorus. In some gardens, drastic changes of soil $\mathrm{pH}$ or aluminum level will be necessary to accomplish the desired change in flower color. These manipulations may be difficult to achieve and could affect health of French hydrangea and other nearby plants.

General guidelines for changing flower color are given below. Specific guidelines for Florida soils are not available because additional research is needed. Furthermore, these guidelines were developed for French hydrangeas that bloom just once each year. It is not clear how these general guidelines will affect season-long flower color of everblooming French hydrangea.

\section{Change Blue Flower Color to Pink or Purple with Lime}

Lime applied to soil raises $\mathrm{pH}$ and reduces the availability of aluminum, resulting in pink or purple flowers. For long-term changes to soil $\mathrm{pH}$, a soil test can determine current $\mathrm{pH}$ and provide recommendations for annual liming to achieve and maintain the $\mathrm{pH}$ of 6.5 needed for pink flowers.

For short-term changes to soil $\mathrm{pH}$, most recommendations suggest drenching soil around well-watered French hydrangea with hydrated lime (available at garden supply stores) mixed at a rate of 1 tablespoon per gallon of water. Apply drenches monthly in February, March and April. 


\section{Change Pink Flower Color to Blue or Purple by Adding Aluminum}

Addition of aluminum sulfate to soil will increase the amount of aluminum available to roots, almost guaranteeing blue or purple flower color. Also known as alum, aluminum sulfate is widely available at garden supply stores.

Most recommendations call for drenching soil around well-watered French hydrangea with aluminum sulfate mixed at a rate of 1 tablespoon per gallon of water. Apply drenches monthly in February, March and April, avoiding contact with leaves since this solution can damage foliage.

Ignore any recommendations listed on bags of aluminum sulfate to apply it at higher rates than those recommended above. These rates will lower soil $\mathrm{pH}$ but increase risk of accidental application of excess levels of aluminum that are toxic to many other garden plants.

\section{Lowering Soil pH Is Often Difficult and Doesn't Guarantee Blue Flower Color}

Efforts to lower soil pH with "acid-forming" fertilizer, aluminum sulfate or elemental sulfur usually aren't effective because most soils quickly revert to their natural $\mathrm{pH}$. Acid-forming fertilizer does not significantly lower $\mathrm{pH}$ of most soils.

For long term effectiveness, elemental sulfur or aluminum sulfate must be routinely applied or blended into the soil of the entire root zone to ensure all flowers are blue. This can damage plant roots and usually is not practical. Low soil $\mathrm{pH}$ will not produce blue flowers in high phosphorus soils. Phosphorus ties up aluminum and prevents blue flower color development regardless of soil $\mathrm{pH}$.

\section{Hydrangea Pests}

French hydrangea is nearly pest-free when properly placed in the garden and not stressed. Plant French hydrangea in full shade or at least in areas shaded from afternoon sun. Avoid wet soils and don't plant too deeply or root systems will be stressed and unable to function properly.

\section{Insects and Mites}

The following insects and mites are pests of French hydrangea but are not commonly found unless hydrangea is stressed:

- Aphids are found primarily on new growth.

- Oystershell scale typically occurs on upper stems.

- Four-lined plant bug causes round, brown, sunken spots on leaves.

- Leaf tiers are indicated by webbing between leaf tips.

- Rose chafers are light tan beetles that damage leaves, usually when French hydrangea is grown on sandy soils.

- Mites occasionally may infest French hydrangea.

These pests generally do not threaten plant health and often disburse naturally. When present, these pests can be controlled by removing them by hand, pruning affected branches and applying horticultural soaps and oils.

\section{Deer}

Deer occasionally damage French hydrangea. Deer will eat French hydrangea leaves, but they seem to prefer the native Hydrangea species $H$. arborescens and $H$. quercifolia.

\section{Diseases}

A number of diseases can affect French hydrangea but only powdery mildew and leaf spot are typically encountered in the garden.

Powdery mildew appears as small white patches on the undersides of leaves followed by purple or yellow blotches on the tops of leaves. It is primarily an aesthetic problem and does not seriously threaten plant health. Powdery mildew occasionally occurs in spring and fall when days are warm and humid and nights are cool. Powdery mildew can be prevented by using resistant selections of hydrangea. 
A leaf spot caused by Cercospora or Corynespora often occurs in the garden, usually during late summer and fall. It appears as small brown or purple spots on leaves. The leaf spot is primarily an aesthetic problem and does not threaten plant health, although it can defoliate plants when severe. It can be controlled by removing dead and diseased leaves and avoiding overhead irrigation.

Several diseases rarely occur on garden-grown French hydrangea:

- Anthracnose, caused by Colletotrichum fungi, can occur during hot, wet weather on plants with succulent growth. Anthracnose initially appears as circular brown spots on leaves that then form irregular patches; older spots turn tan.

- Botrytis blight occurs occasionally on flowers during cool, humid, wet conditions. It initially appears as small, water-soaked spots on petals that then form irregular reddish-brown patches.

- Mushroom root rot can occur in gardens where oak trees were or are present. Mushroom root rot appears as sudden wilting of a branch or shoot.

These diseases can be prevented or controlled by keeping plants as healthy as possible, avoiding overhead irrigation and removing dead or diseased leaves.

\section{Future Hydrangeas}

Watch for new everblooming French hydrangeas. The popularity of these everblooming plants has prompted many new breeding efforts. In addition, breeders are working to develop French hydrangeas with additional ornamental characteristics, such as colorful stems or leaves, as well as greater disease resistance and hardiness.

\section{References}

Dirr, Michael A. 2004. Hydrangeas for American gardens. Timber Press, Inc., Portland, OR. King, Judith. Hydrangeas! Hydrangeas! $<$ http://hydrangeashydrangeas.com/> Accessed 10
January 2007.

Fox, A.M., D.R. Gordon, J.A. Dusky, L. Tyson, and R.K. Stocker. 2005. IFAS Assessment of the Status of Non-Native Plants in Floridas Natural Areas. <http://plants.ifas.ufl.edu/assessment.html> Accessed 7 February 2007.

Griffith, Gene and E. Dean. Wilkerson Mill Gardens Catalog. <http://www.hydrangea.com/> Accessed 10 January 2007.

Hagan, Austin K. and Jackie M. Mullen. 2001. ANR-1212, Diseases of hydrangea.

$<$ http://www.aces.edu/pubs/docs/A/ANR-1212/ANR1212.pdf $>$ Accessed 10 January 2007. Alabama Cooperative Extension System, Auburn University, Auburn, AL. Oct., 2001.

Knox, Gary W. 2006. ENH1034, New Hydrangeas for North and Central Florida: Bigleaf and Mountain Hydrangeas (http://edis.ifas.ufl.edu/EP287). Florida Cooperative Extension Service, Institute of Food and Agricultural Sciences, University of Florida, Gainesville, FL. March 16, 2006.

Knox, Gary W. 2007. NFREC Research Report 2007-2, 2006 Flowering of Hydrangea macrophylla Selections at the University of Florida/IFAS North Florida Research and Education Center in Quincy. University of Florida/IFAS North Florida Research and Education Center, 155 Research Rd., Quincy, FL $32351.5 \mathrm{pp}$.

Wade, Gary L. Growing Bigleaf Hydrangea. Fact Sheet H-92-011, The University of Georgia College of Agricultural \& Environmental Sciences, Cooperative Extension Service, Athens, GA. 